Jurnal Penelitian dan Pengabdian Kepada Masyarakat Bidang ilmu Pendidikan

\title{
Efektivitas Media Animasi Audio Visual dalam Kuliah Daring Keterampilan Membaca
}

1) Fatih Holis Ahnaf, 2) Farida Rochmawati, 3) Sri Maria Utami, 4) Dini Dwi Syahputri

1), 2) Dosen Tadris Bahasa Indonesia Universitas Islam Zainul Hasan Genggong

3),4) Mahasiswa Tadris Bahasa Indonesia Universitas Islam Zainul Hasan Genggong

E-mail: fatihholis1212@gmail.com

Article History: Received: 2021-01-05 || Revised: 2021-02-15 || Published: 2021-03-02

Sejarah Artikel : Diterima: 2021-01-05 || Direvisi: 2021-02-15 || Dipublikasi: 2021-03-02

\begin{abstract}
The purpose of this study was to test the effectiveness of the use of audio-visual animation media in bold lectures with conventional learning models. The subjects of this study were divided into two groups, the experimental group and the control group. Student learning outcomes were tested using summative cognitive tests through descriptive analysis test. The results obtained from the experimental group 88.84 and the control group 78.91. From these calculations there is a significant difference between the learning outcomes of students who use learning media and students who still use conventional learning models. From this it can be concluded that the audio-visual animation learning media is effectively used, especially in reading subjects.
\end{abstract}

Keywords: Learning Media, Animation, Audio visual, Reading

\begin{abstract}
Abstrak
Tujuan penelitian ini adalah untuk menguji efektifitas antara penggunaan media animasi audio visual dalam perkuliahan daring dengan model pembelajaran konvensional. Subjek penelitian ini terbagi menjadi dua kelompok, kelompok eksperimen dan kelompok kontrol. Hasil belajar mahasiswa diuji menggunakan tes kognitif sumatif melalui uji analisis deskriptif. Hasil yang diperoleh dari kelompok eksperimen 88,84 dan kelompok kontrol 78,91. Dari perhitungan tersebut terdapat perbedaan yang signifikan antara hasil belajar mahasiswa yang menggunakan media pembelajaran dengan mahasiswa yang masih menggunakan model pembelajaran konvensional. Dari sini dapat ditarik kesimpulan bahwa media pembelajaran animasi audio visual efektif digunakan, khususnya pada mata kuliah membaca.
\end{abstract}

Kata kunci: Media Pembelajaran, Animasi, Audio visual, Membaca

\section{PENDAHULUAN}

Teknologi memiliki cakupan yang luas, begitupun terhadap ranah pendidikan. Ada begitu banyak hal yang dikembangkan untuk mempermudah proses belajar mengajar. Perangkat dan fasilitas modern turut serta membantu dalam hal mengoptimalisasi kegiatan pembelajaran menjadi lebih mudah. Salah satu kemudahan yang diperoleh adalah kecepatan penyampaian informasi tanpa terbatas ruang dan waktu, hal ini dapat terlampaui jika sistem pembelajaran seperti ini di dukung oleh sebuah jaringan agar dapat terhubung dengan mudah antara satu dengan yang lain, (online). Perlahan namun pasti sistem seperti ini akan menggeserkan paradigma lama yang cenderung memusatkan pembelajaran pada guru melalui proses ceramah, menjadi pembelajaran yang di dominasi oleh siswa dan bahkan dari perkembangan tersebut sudah banyak develop/pengembang yang berfokus pada dunia pendidikan mengembangkan berbagai media pembelajaran yang tidak membutuhkan guru. Karena pada dasarnya guru bukanlah satu-satunya sumber belajar yang dapat dimanfaatkan oleh pembelajar.

Pembelajaran secara tatap muka memang dapat dikatakan efektif, tetapi ada beberapa hal yang menyebabkan proses tersebut tidak dapat dilakukan. Salah satunya yaitu situasi dan kondisi pada saat terjadi wabah (pandemi). Jika dilihat dari perkembangan teknologi maka kita sudah mampu untuk melakukan pembelajaran secara daring, karena tidak menutup kemungkinan banyak hal positif yang diperoleh ketika belajar secara daring. Hal ini tentunya harus di dukung dengan media 
yang sesuai untuk memenuhi kebutuhan belajar mahasiswa. Salah satu alternatif yang dapat digunakan adalah media animasi audio visual. Disamping itu Djamarah (2006:120) mengatakan bahwa penggunaan media secara harfiah berarti perantara. Perantara yang dimaksud adalah media pembelajaran berbasis audio visual digunakan sebagai perantara pembelajaran yang tepat pada saat perkuliahan daring.

Pembelajaran merupakan satu hal yang kompleks sehingga diperlukan alat bantu berupa media yang relevan untuk menyampaikan berita/informasi, yang dapat merangsang minat, pemikiran, emosi, serta perhatian siswa terhadap materi pembelajaran. hal ini tidak terlepas dari penggunaan media pembelajaran. media pembelajaran banyak hal Salah satunya yaitu media pembelajaran audio visual lakukan dengan tujuan. Berbagai upaya telah dilakukan dengan tujuan untuk meningkatkan kualitas pendidikan, subjek yang tidak terlepas dari pendidikan adalah guru. Guru dituntut agar mampu menumbuhkan motivasi dan kreativitas siswa maupun mahasiswa melalui pengembangan media pembelajaran sehingga dapat diakses secara mandiri, hal ini ditujukan agar media yang telah tersusun sesuai dengan tipe, dan karakter dari siswa, serta menargetkan perubahan perilaku siswa agar sesuai dengan tujuan maupun target yang ingin dicapai. Opsi yang dapat dipilih sebagai media pembelajaran dikarenakan kemudahannya dalam proses pengemasan adalah media pembelajaran berbasis audiovisual.

Media audiovisual adalah salah satu media yang dipercaya mampu merangsang motivasi serta minat seseorang dalam belajar. Pada satu sisi, jenis media ini adalah satu pilihan yang dapat digunakan guru dalam penyelenggaraan pembelajaran berbasis teknologi. Ditinjau dari berbagai aspek, pembelajaran yang berbasis audiovisual dapat dimanfaatkan sebagai pilihan alternatif untuk mengoptimallisasikan pembelajaran, adapun kemudahan yang dapat diperoleh dengan menggunakan media pembelajaran berbasis audiovisual adalah; (a) kemudahan dalam proses pengemasan, (b) menarik motivasi siswa, (c) kemudahan proses editing (rombak kembali), (d) kemudahan akses secara daring (online) maupun tatap muka secara langsung. Melalui pemanfaatan teknologi komputer, pembelajaran audiovisual diharapkan mampu menyajikan materi yang lebih bervariatif, termasuk visualisasi sebuah bahan ajar bahan ajar, sehingga mampu meningkatkan kemampuan siswa saat belajar. Disamping itu Pembelajaran audiovisual dapat dilakukan secara interaktif, melalui lalu lintas dua arah antara guru, siswa, dan media, yang terjadi selama proses pembelajaran.

Keterampilan membaca, merupakan kemampuan yang wajib dimiliki oleh mahasiswa jurusan Bahasa Indonesia, karena pada dasarnya membaca adalah proses yang kompleks, terutama pada membaca nyaring. Dibutuhkan kemampuan khusus yang perlu dilatih secara intensif agar memiliki kualitas membaca yang baik, bukan hanya untuk dirinya sendiri, bahkan untuk masyarakat luas. Oleh karena itu pembelajaran membaca diperlukan sebuah media yang mampu memberikan stimulus serta gambaran secara objektif mengenai kegiatan membaca, terlebih pada saat pembelajaran daring berlangsung. Melalui media audiovisual dapat memungkinkan mahasiswa untuk memahami dan memberi contoh dengan fleksibilitas yang tinggi. Selain itu, metode media audiovisual memiliki efisiensi dari segi waktu dan materi yang dipelajari.

Berdasarkan latar belakang tersebut, maka pertanyaan tentang "bagaimana efektifitas penggunaan media audiovisual dalam kuliah daring keterampilan membaca pada jurusan Tadris bahasa Indonesia fakultas Tarbiyah Universitas Islam Zainul Hasan Genggong. Adapun tujuan dari penelitian ini adalah untuk mengetahui hasil belajar mahasiswa sebelum sesudah dan mendeskripsikan efektivitas media pembelajaran berbasis audio visual untuk materi membaca pada mahasiswa Tadris bahasa Indonesia Universitas Islam Zainul Hasan Genggong. Di lain sisi penelitian ini diharapkan mampu memotivasi Para dosen lainnya untuk turut serta mengembangkan kemampuannya dalam mengajar melalui media pembelajaran yang inovatif kreatif dan menarik. Selain itu dapat membantu proses belajar mahasiswa menjadi lebih optimal.

\section{Media Pembelajaran Audio Visual}

Secara umum media adalah suatu alat suatu teknik maupun metode yang digunakan untuk mempermudah proses pembelajaran. hal ini sependapat dengan pendapat Arsyad (2007:3) mengungkapkan bahwa Secara garis besar media pembelajaran adalah manusia, Pengalaman yang membuat seseorang mengalami proses belajar. hal ini tidak terlepas dengan pemerolehan pengetahuan, sikap dan keterampilan. Pemahaman dalam dunia teknologi menjadi sesuatu yang 
penting terlebih bagi seorang guru dalam menjalankan profesinya sebagai seorang pengajar. Tidak hanya sekedar mengenal, Seorang guru dituntut untuk mampu menguasai dan turut ikut andil dalam perkembangan teknologi di dunia pendidikan

Terdapat dua karakteristik utama dari media audio visual Jika dilihat dari pembentukan katanya Audio berarti suara sedangkan visual berarti tampilan ataupun gambar. Jenis media anggap memiliki kemampuan yang lebih baik dalam hal penyampaian materi pembelajaran kepada. selanjutnya terbaik Menjadi dua yaitu; (1) Media Visual diam, Dan media visual bergerak. Pada penelitian ini peneliti menggunakan media visual gerak dalam penyampaian materi pelajaran.

Ciri-ciri efektivitas sebuah media pembelajaran adalah; (1) tingkat keseriusan audiens, Motivasi belajar, dan Suasana belajar. terlebih ada media audio yang Dapat memunculkan emosi serta sikap keseriusan dalam belajar. Di samping itu Motivasi, minat, serta rangsangan baru pada saat belajar akan terbentuk hal ini tentu membantu efektivitas media pembelajaran yang tentunya akan berpengaruh pada hasil belajar siswa/mahasiswa Arsyad (2007: 15). Adapun ciri lainnya yaitu, media pembelajaran berbasis audio visual memiliki keunggulan, salah satunya yaitu, dapat digunakan secara daring maupun luring. saat ini kemudahan teknologi dan informasi sudah sangat membantu dengan adanya berbagai platform yang menyediakan wadah untuk mengunggah suatu video yang paling umum adalah YouTube. melalui tersebut Guru maupun pengembang dapat dengan mudah mengembangkan sebuah media pembelajaran yang berbasis audio visual. Hal ini tentu menjadi sebuah alternatif yang baik untuk mempersiapkan siswa maupun mahasiswa Agar dapat belajar secara mandiri terlebih situasi dan kondisi yang Tidak selalu baik-baik saja. contoh kita diharuskan untuk melakukan pembelajaran secara online dikarenakan pandemi virus corona. Guru/dosen yang menerapkan sistem pembelajaran lama berbasis ceramah maka akan sangat menyulitkan dan pastinya akan berpengaruh terhdap hasil belajar siswa/mahasiswa. Untuk itu video pembelajaran audio visual dirasa tepat untuk digunakan sebagai alternatif pembelajaran daring.

Hasil pembelajaran merupakan suatu acuan yang harus dicapai oleh siswa/mahasiswa sebagai alat ukur dalam menentukan tingkat keberhasilan pembelajaran. proses ini dapat dilakukan dengan melakukan tes kepada siswa untuk menguji Pemahaman terhadap materi yang telah dipelajari. Hasil belajar ini pada umumnya berupa angka dari yang telah digunakan untuk mengukur keberhasilan belajar. Hal ini diperkuat dengan pernyataan Dimyati (2006:3-4) yang menyatakan bahwa hasil belajar adalah hasil dari suatu interaksi antara guru dan siswa yang diakhiri dengan proses evaluasi. Dari beberapa hal yang telah di paparkan sebelumnya maka dapat disimpulkan bahwa hasil belajar adalah hasil yang dicapai seseorang dalam kurun waktu tertentu dengan kata lain Hasil ini mengacu pada perubahan tingkah laku dalam kurun waktu tertentu jadi hasil belajar keterampilan membaca dapat dikatakan sebagai satu hasil belajar yang dicapai oleh sia mah setel melakukan proses kegiatan belajar dan keterampilan. Hasil belajar yang ingin di ukur dalam penelitian ini adalah kemampuan mahasiswa Setelah belajar menggunakan media audio visual pada saat pembelajaran daring.

Salah satu waktu Faktor penunjang keberhasilan belajar adalah penggunaan media pembelajaran yang tepat. jika dibandingkan Dengan pendekatan konvensional, Jelas terdapat perbedaan yang signifikan itu disebabkan oleh peran guru yang lebih aktif dalam proses pembelajaran sedangkan siswa/mahasiswa cenderung pasif. di sisi lain kurangnya Inovasi dan kreativitas guru/dosen dalam menyampaikan pemahamannya terhadap mahasiswa. berbeda halnya dengan menggunakan media pembelajaran khususnya media pembelajaran audio visual karena media ini dipercaya dapat memperlancar pemahaman dan memperkuat Ingatan siswa/mahasiswa sehingga potensi dan kemampuan mahasiswa diharapkan dapat optimalisasi dengan baik, terlebih digunakan saat pembelajaran dalam jaringan (daring). Media pembelajaran berbasis audio visual yang telah dirancang selanjutnya melalui proses uji coba. Uji coba ini dilakukan pada mata kuliah keterampilan membaca tahun ajaran 2020/2021 Prodi Tadris bahasa Indonesia, fakultas Tarbiyah, Universitas Islam Zainul Hasan Genggong. Selanjutnya hipotesis yang diajukan dalam penelitian ini adalah pendapat apakah pembelajaran dengan menggunakan media audio visual lebih efektif dibandingkan dengan media pembelajaran konvensional Jika dilihat dari situasi pembelajaran yang dilakukan secara daring?" 


\section{METODE PENELITIAN}

Penelitian ini merupakan penelitian eksperimen pre-test- post-test control group design. variabel yang menjadi patokan dalam penelitian ini adalah hasil belajar mahasiswa Setelah menggunakan media pembelajaran audio visual secara daring dalam keterampilan membaca. Selanjutnya untuk mengerjakan variabel yang di dalam penelitian ini adalah dengan memberikan batasan-batasan sebagai berikut; (a) Bagaimanakah hasil belajar keterampilan membaca sebelum menggunakan media pembelajaran audio visual secara daring, (b) Bagaimanakah hasil belajar keterampilan membaca sebelum menggunakan media pembelajaran audio visual secara daring?, (c) Bagaimanakah efektivitas hasil belajar keterampilan membaca dengan menggunakan media pembelajaran audio visual secara daring?

Populasi yang digunakan dalam penelitian ini adalah seluruh mahasiswa yang mengampu mata kuliah membaca tahun ajaran 2020/2021, Jurusan bahasa Indonesia fakultas Tarbiyah, Universitas Islam Zainul Hasan Genggong, dengan jumlah 43 mahasiswa. Total populasi ini kemudian dibagi menjadi dua kelompok. Kelompok A (eksperimen) dengan jumlah orang sebanyak 23 mahasiswa menggunakan media pembelajaran audio visual secara daring, dan Kelompok B (kontrol) dengan jumlah orang sebanyak 22 mahasiswa menggunakan Pembelajaran konvensional. Kemudian penelitian ini diawali dengan menerapkan pola perlakuan yaitu penggunaan media audio visual dalam mata kuliah keterampilan membaca. Selanjutnya proses ini beberapa tahap; (a) Tahap persiapan meliputi observasi, Mempersiapkan strategi, indikator, pokok bahasan, lokasi, dan waktu untuk proses penerapan penelitian media audio visual mata kuliah keterampilan membaca. Pemilihan waktu dibagi menjadi dua, hal ini disesuaikan dengan pengujian efektivitas media. Oleh karena itu diperoleh atau lokasi di kampus (kelompok kontrol) dan secara online (kelompok eksperimen), (b) pelaksanaan, tahap ini meliputi Pelaksanaan kegiatan pembelajaran menggunakan media audio visual terdapat tiga tahap yaitu orientasi latihan, umpan balik dan lanjutan. kereta api ini dilakukan pada kedua kelas yang menjadi subjek penelitian yaitu kelas kontrol dan kelas eksperimen.

Silabus mata kuliah dijadikan sebagai acuan pengembangan instrumen mulai dari pokok bahasan sampai sub pokok bahasan serta indikator apa saja yang akan dicapai pada saat pelaksanaan berlangsung. Adapun instrumen yang digunakan dalam penelitian ini adalah instrumen tes menggunakan model tes hasil belajar mahasiswa yang di dalamnya terdapat 5 pilihan opsi jawaban. Selanjutnya adalah memberikan tes pada awal pelaksanaan, hal ini dilakukan sebelum penerapan media pembelajaran pada kelas eksperimen kemudian baru dilakukan tes akhir yang berupa soal untuk mengetahui tingkat Pemahaman mahasiswa terhadap media pembelajaran audio visual berbasis online. Data yang diperoleh berdasarkan hasil tes selanjutnya akan dianalisa menggunakan teknik statistik deskriptif dan statistik inferensial. statistik deskriptif digunakan untuk mendeskripsikan skor mahasiswa yang menjadi subjek penelitian. sedangkan statistik inferensial digunakan untuk menguji hipotesis yang meliputi uji kesamaan dua rata-rata dengan menerapkan statistik T. Uji normalitas dan uji homogenitas varians dilakukan untuk keperluan uji hipotesis Hal ini dilakukan untuk meminimalisasi kesalahan perhitungan. penghitungan data ini dibantu dengan software SPSS versi 22.

\section{HASIL DAN PEMBAHASAN}

Hasil dalam penelitian ini diuraikan dalam bentuk data yang menunjukkan pemerolehan skor mahasiswa dari dua kelompok yakni kelompok eksperimen dan kelompok kontrol yang terdiri dari 23 mahasiswa kelompok eksperimen, dan 22 mahasiswa kelompok kontrol. Selanjutnya pada proses analisis responden ambil sejumlah 12 orang sebagai sampel untuk masing-masing kelompok proses ini dilakukan secara acak.

Tabel 1. Pemerolehan Skor Pre-test dan Post-test

\begin{tabular}{ccccccc}
\hline & \multicolumn{3}{c}{ kelompok kontrol } & \multicolumn{3}{c}{ kelompok eksperimen } \\
\cline { 2 - 7 } & Pre-test & Post Test & Gain Score (\%) & Pre-test & Post Test & $\begin{array}{c}\text { Gain Score } \\
\text { (\%) }\end{array}$ \\
\hline 1 & 71 & 81 & 34 & 63.5 & 83.5 & 56 \\
\hline 2 & 68.5 & 72.5 & 29 & 66 & 81 & 44 \\
\hline 3 & 61 & 81 & 51 & 71 & 81 & 34 \\
\hline
\end{tabular}




\begin{tabular}{ccccccc}
\hline 4 & 71 & 81 & 34 & 67.6 & 83.6 & 50 \\
\hline 5 & 74 & 81 & 27 & 73 & 91 & 67 \\
\hline 6 & 65.5 & 77.4 & 38 & 71 & 83.0 & 48 \\
\hline 7 & 75 & 85 & 40 & 72.5 & 93.5 & 85 \\
\hline 8 & 66 & 71 & 15 & 65 & 86 & 60 \\
\hline 9 & 71 & 75 & 14 & 76 & 91 & 63 \\
\hline 10 & 78 & 85 & 32 & 76 & 91 & 63 \\
\hline 11 & 72 & 81 & 32 & 63.5 & 82.5 & 57 \\
\hline 12 & 65 & 76 & 31 & 76 & 95 & 79 \\
\hline jumlah & $\mathbf{7 0 4}$ & $\mathbf{7 9 7}$ & $\mathbf{3 7 7}$ & $\mathbf{5 7 4}$ & $\mathbf{6 1 6}$ & $\mathbf{7 0 6}$ \\
\hline $\begin{array}{c}\text { Rata- } \\
\text { rata }\end{array}$ & $\mathbf{7 0 , 4}$ & $\mathbf{7 9 , 7}$ & $\mathbf{3 1 , 4 2}$ & $\mathbf{7 1 , 7 5}$ & $\mathbf{8 8}$ & $\mathbf{5 8 , 8 3}$ \\
\hline
\end{tabular}

Tabel 2. Tests of Normality

\begin{tabular}{lllllcrr}
\multirow{2}{*}{ Kelas } & \multirow{2}{*}{ Kolmogorov-Smirnova } & \multicolumn{3}{c}{ Shapiro-Wilk } \\
\cline { 2 - 8 } Hasil Belajar & Statistic & df & Sig. & Statistic & df & Sig. \\
\cline { 2 - 8 } & Pre-Test Experimen & .158 & 12 & $.200^{*}$ & .895 & 12 & .135 \\
\cline { 2 - 8 } & Post-Test Experimen & .237 & 12 & .061 & .876 & 12 & .077 \\
\cline { 2 - 8 } & Pre-test Kontrol & .179 & 12 & $.200^{*}$ & .976 & 12 & .961 \\
\cline { 2 - 8 } & Post-Test Kontrol & .261 & 12 & .023 & .913 & 12 & .233 \\
\hline
\end{tabular}

Dapat di interpretasikan bahwa berdasarkan hasil uji normalitas memperoleh skor sig pada uji Kolmogorov-smirnov $(0.200)$ dan shapiro-wik $(0,135)$ pada tabel menunjukan angka lebih besar dari 0,5, maka dapat disimpulkan bahwa data berdistribusi normal Nasution (2009:80). Sedangkan uji homogenitas memperoleh skor sebesar 0,367 > 0,05 yang berarti bahwa data hasil belajar mahasiswa adalah homogen. Selanjutnya data tersebut diuji menggunakan T-tes. Hasil dari tes tersebut dapat diamati pada tabel berikut ini.

Tabel 3. Paired Samples Test

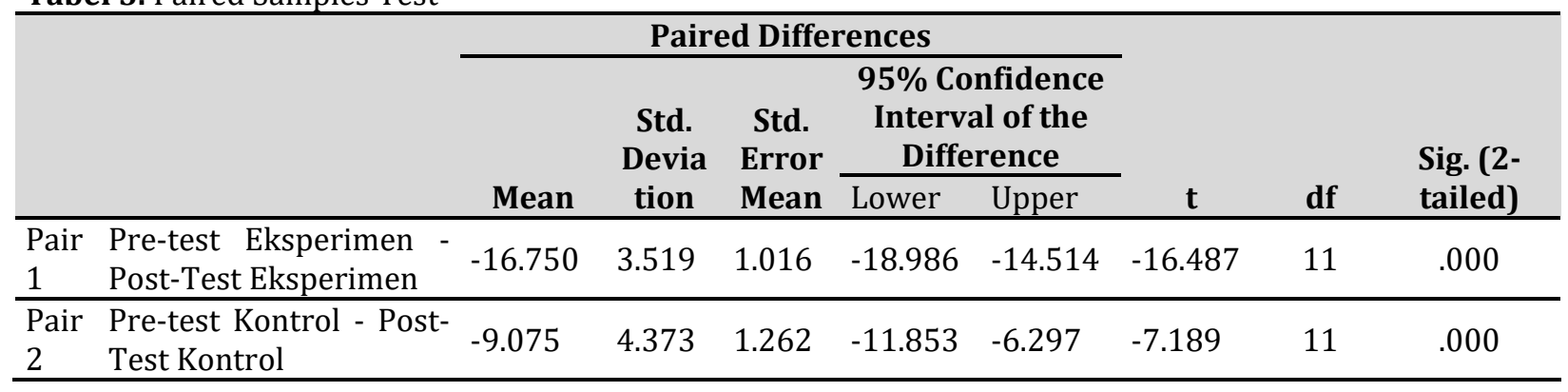

Diketahui bahwa skor yang diperoleh pada nilai sig 1 dan sig 2 sebesar $0.000<0,05$ maka dapat disimpulkan bahwa terdapat perbedaan rata-rata untuk hasil belajar mahasiswa. Artinya terdapat pengaruh antara sebelum dan sesudah menggunakan media pembelajaran audio visual untuk mata kuliah membaca. Untuk mengetahui seberapa besar pengaruh dapat dilihat pada hasil statistik deskriptif uji paired sample t-tes berikut ini.

Tabel 4. Paired Samples Statistics

Mean N $\quad$ Std. Deviation Std. Error Mean

\begin{tabular}{llllll}
\hline Pair 1 & Pre-test Eksperimen & 70.09 & 12 & 4.828 & 1.394 \\
\cline { 2 - 6 } & Post-Test Eksperimen & 86.84 & 12 & 5.108 & 1.475 \\
\hline \multirow{2}{*}{ Pair 2 } & Pre-test Kontrol & 69.83 & 12 & 4.826 & 1.393 \\
\cline { 2 - 6 } & Post-Test Kontrol & 78.91 & 12 & 4.530 & 1.308 \\
\hline
\end{tabular}


Perbedaan yang signifikan berada pada nilai rata-rata hasil belajar mahasiswa yang menunjukan skor sebesar 78,91 untuk post-test kelas kontrol, sedangkan untuk pos-test kelas eksperimen memperoleh skor sebesar 86,84. Artinya dari perbedaan tersebut terdapat peningkatan ketika menggunakan media pembelajaran audio visual dalam perkuliahan daring keterampilan membaca. Setelah melewati beberapa tahap perhitungan pada SPPS selanjutnya adalah melakukan uji independen sample t-test hal in dilakukan untuk mengetahui perbedaan skor rata-rata pada dua sampel yang tidak berpasangan. Namun sebelum melakukan tahapan ini data yang diperoleh harus melewati uji normalitas untuk mengetahui apakah data yang diolah berdistribusi normal atau tidak. Pada penelitian ini hasil uji normalitas mendapat skor uji Kolmogorov-smirnov (0.200) dan shapiro-wik $(0,135)>0,05$ Sugiyono (2016:80). Dari angka tersebut dapat diartikan bahwa data pada penelitian ini berdistribusi normal dan homogen. Hal ini tentu sudah memenuhi syarat untuk melanjutkan pada tahap uji independent Sample T-test. Berikut ini merupakan hasil dari tahap uji independent sample T-test.

Tabel 5. Group Statistics

\begin{tabular}{llcccc}
\hline & \multicolumn{1}{c}{ kelas } & N & Mean & $\begin{array}{c}\text { Std. } \\
\text { Deviation }\end{array}$ & $\begin{array}{c}\text { Std. Error } \\
\text { Mean }\end{array}$ \\
\hline $\begin{array}{l}\text { Hasil Belajar } \\
\text { Mahasiswa }\end{array}$ & $\begin{array}{l}\text { Post-test kelas } \\
\text { Eksperimen }\end{array}$ & 12 & 86.84 & 5.108 & 1.475 \\
\cline { 2 - 6 } & Post-Test Kelas Kontrol & 12 & 78.91 & 4.530 & 1.308 \\
\hline
\end{tabular}

Berdasarkan pada tabel diatas terdapat perbedaan yang signifikan antara nilai rata-rata yang diperoleh dari post-test kelas eksperimen mendapat skor sejumlah 86,84, Sedangkan pada kelas kontrol memperoleh skor 78,91. Data ini turut diperkuat dengan pemerolehan skor gain 31,42 untuk kelas kontrol, dan 58,83 pada kelas eksperimen. Dari data tersebut dapat disimpulkan bahwa penggunaan media pembelajaran animasi audio visual Efektif digunakan pada materi keterampilan membaca.

\section{SIMPULAN DAN SARAN}

\section{A. Simpulan}

Diketahui nilai rata-rata pada subjek penelitian mahasiswa sebelum menerapkan media pembelajaran video sebesar pre-tests 69,83, dan post-test 78,81, (kelas kontrol). Sedangkan pada kelas eksperimen memperoleh skor pre-tests 70,09 , dan post-test 86,84 . Data ini turut diperkuat dengan pemerolehan skor gain 31,42 untuk kelas kontrol, dan 58,83 pada kelas eksperimen. Dari pemerolehan skor tersebut terdapat perbedaan yang signifikan sehingga dapat disimpulkan bahwa penggunaan media audio visual berbasis animasi memiliki pengaruh pada hasil belajar, dan efektif digunakan pada perkuliahan daring keterampilan membaca.

\section{B. Saran}

Kepada dosen Tadris bahasa Indonesia Universitas Islam Zainul Hasan Genggong. Berdasarkan tingkat efektifitas yang diperoleh dari penggunaan media pembelajaran pada perkuliahan daring, dosen dapat mengembangkan dan menggunakan media pembelajaran yang inovatif, dan kreatif untuk menunjang kebutuhan belajar mahasiswa, sedangkan Kepada lembaga dan instansi pendidikan, sudah seharusnya beralih, serta memanfaatkan teknologi untuk mengoptimalisasi kegiatan belajar mahasiswa. Disamping itu media pembelajaran audio visual dapat memperkaya model pembelajaran di bidang pendidikan.

\section{DAFTAR RUJUKAN}

Dimyati. 2006. Belajar dan Pembelajaran. Jakarta: Rineka Cipta.

Djaali. 2007. Psikologi Pendidikan. Jakarta: Bumi Aksara.

Djamarah, S,B, dan Zain,A. Strategi Belajar Mengajar, (Jakarta: PT. Rineka Cipta, 2006)

Fathirma'ruf, F., \& Said, M. B.(2020). Pengembangan Perangkat Pembelajaran Konstruktivistik Model Teaching with Analogies (TWA) pada Mata Kuliah Database Management System 
(DBMS) untuk Meningkatkan Kemampuan Berpikir Kreatif Mahasiwa. Jurnal Teknologi Informasi dan Ilmu Komputer, 7(5), 1051-1060.

S. Nasution. 2009. Metodologi Research.jakarta: Bumi Aksara.

Sadiman, A. Dkk. 2006. Media Pendidikan Pengertian, Pengembangan dan Pemanfaatannya. Jakarta: PT Raja PraGrafindo Persada.

Sadiman, A. Dkk. 2014. Media Pendidikan. Jakarta: PT Raja PraGrafindo Persada.

Sanjaya, W.2013. Penelitian Pendidikan Jenis, Metode dan Prosedur. Jakarta: Kencana.

Setyosari, P. 2015. Metode Penelitian Pendidikan dan Pengembangan. Jakarta: PT Kharisma Putra Kencana.

Trianto. 2007. Model Pembelajaran Inovatif Berorientasi Kontruktivistik. Jakarta: Prestasi Pustaka. 